\title{
ARTICLE Physicochemical Properties of Liquid Infant Formula Stored at Different Temperatures
}

\author{
Chan Won Seo, Shik Hong, Yong Kook Shin, and Shin Ho Kang* \\ R\&D Center, Seoul Dairy Cooperative, Ansan 15407, Korea
}

\section{OPEN ACCESS}

$\begin{array}{ll}\text { Received } & \text { July 6, } 2018 \\ \text { Revised } & \text { August 6, } 2018 \\ \text { Accepted } & \text { August 6, 2018 }\end{array}$

*Corresponding author: Shin Ho Kang

R \& D Center, Seoul Dairy Cooperative,

Ansan 15407, Korea

Tel: $+82-31-481-0110$

Fax: +82-31-491-9179

E-mail: shkang@seoulmilk.co.kr

\begin{abstract}
Changes in the physicochemical properties of ready-to-feed liquid infant formula (LIF) stored at different temperatures $\left(10,20,30\right.$, and $\left.40^{\circ} \mathrm{C}\right)$ for 6 mon, focusing on 5-hydroxymethylfurfural (HMF) content, color, $\mathrm{pH}$, fat globule size distribution, and rheological properties were determined. The HMF content increased with storage time, and LIF stored at $40^{\circ} \mathrm{C}$ had a higher HMF content than that of LIF stored at $10^{\circ} \mathrm{C}$. The lightness $\left(\mathrm{L}^{*}\right)$ decreased while redness $\left(\mathrm{a}^{*}\right)$ and yellowness $\left(\mathrm{b}^{*}\right)$ increased with increasing HMF content. The fat globule size and $\mathrm{pH}$ of LIF stored at $10^{\circ} \mathrm{C}$ did not change. However, in the case of LIF stored at $30^{\circ} \mathrm{C}$ and $40^{\circ} \mathrm{C}$, the fat globule size increased and the $\mathrm{pH}$ decreased during storage for $6 \mathrm{mon}$. LIF stored at $40^{\circ} \mathrm{C}$ had a higher apparent viscosity $\left(\eta_{a, 10}\right)$ than that of LIF stored at $10^{\circ} \mathrm{C}$, and the shear-thinning behavior of LIF stored at higher temperature was stronger than that of LIF stored at low temperature. The physicochemical changes of LIF during storage were accelerated by Maillard reaction (MR) at higher storage temperatures. Therefore, even if LIF is aseptically manufactured, we recommend that sterilized LIF should be stored at low temperature in order to minimize quality changes during storage.
\end{abstract}

Keywords liquid infant formula, storage temperature, 5-hydroxymethylfurfural, Maillard reaction, rheological properties

\section{Introduction}

Human milk is the best source of the nutrients required for the growth of newborn or young infants. However, in the case of mothers who, for a variety of reasons, cannot produce sufficient milk or are unable to breastfeed, infant formula is used as a substitute for mother's milk (Drapala et al., 2016; Nguyen et al., 2018; Sabater et al., 2018). Most infant formulas are made from bovine milk, but bovine milk has a different composition to that of human breast milk. For example, bovine milk has a higher protein content than human milk, and the whey protein to casein ratio in bovine milk is 20:80 whereas it is 60:40 in human milk (Chávez-Servín et al., 2015; McCarthy et al., 2012). Therefore, the bovine-milk content of bovine-milk-based infant formulas should be limited in order to adjust its composition to be more like that of human milk and they are manufactured by blending with nutritional ingredients such as proteins,

(C) Korean Society for Food Science of Animal Resources. This is an open access article distributed under the terms of the Creative Commons Attribution Non-Commercial License (http://creativecommons.org/licences/by-nc/3.0) which permits unrestricted non-commercial use, distribution, and reproduction in any medium, provided the original work is properly cited. 
lipids, carbohydrates, vitamins and minerals (Chávez-Servín et al., 2015; Tham et al., 2017).

Human milk has a higher content of long chain polyunsaturated fatty acids (LCPUFAs) than bovine milk. Vegetable oils are typically used as lipid sources to adjust the composition of human milk, and the types of vegetable oils used in manufacturing infant formula are palm, coconut, soybean, and high oleic sunflower oils (Cheng et al., 2017; Nguyen et al., 2018; Tham et al., 2017). Infant formula containing vegetable oils forms an oil-in-water emulsion stabilized by proteins as the primary emulsifiers. Proteins play an important role in stabilizing the oil phase in infant formulas, but emulsions stabilized by proteins alone are unstable during storage and thermal treatments such as pasteurization or sterilization (McCarthy et al., 2012; Murphy et al., 2015; Drapala et al., 2017).

Quality changes in infant formulas can occur owing to chemical reactions during heating and storage (Ferrer et al., 2000). The Maillard reaction (MR) is one of the main chemical reactions that lead to changes in the color and nutritional composition of infant formula. Because infant formulas are typically the only source of nutrition given to infants, changes in their nutritional value are very important and should be minimized as much as possible (Ferrer et al., 2005; Sabater et al., 2018). The MR is very complex and it is initiated by condensation between the carbonyl group of a reducing sugar and the free amino group of an amino acid or protein. Amadori compounds are formed in the first stage of the MR, and furfurals are produced in its advanced stages (Chávez-Servín et al., 2015; Guerra-Hernandez et al., 2002). 5-Hydroxymethylfurfural (HMF) is one of the main furfural products of the MR, and it is a representative indicator used in evaluating the extent of the MR and quality change during storage (Albalá-Hurtado et al., 1999; Guerra-Hernandez et al., 2002; Sabater et al., 2018).

The physicochemical stability of infant formula during storage is very important due to its complex matrix, which contains various compounds, and most studies have mainly focused on powdered infant formulas (Chávez-Servín et al., 2005; ChávezServín et al., 2015; Cheng et al., 2017; Ferrer et al., 2005; Tham et al., 2017). However, consumption of ready-to-feed liquid infant formula (LIF) in Korea has recently increased owing to its convenience. Accordingly, the aim of this study was to investigate the physicochemical changes in LIF at different storage temperatures $\left(10,20,30\right.$, and $\left.40^{\circ} \mathrm{C}\right)$ over 6 mon.

\section{Materials and Method}

\section{Manufacture of liquid infant formula (LIF)}

The LIF used in this study was produced by successive treatments in two industrial plants to perform emulsification and aseptic filling, respectively. First, an emulsion mixed with vegetable oils was prepared by Nature \& People Co., Ltd. (Damyang, Korea). The vegetable oils were blended with pre-heated water at $90^{\circ} \mathrm{C}$, and then milk, lactose, oligosaccharide, whey protein concentrate, and fat-soluble vitamins were added to the emulsion. Next, the emulsion was homogenized at 230 bar. The homogenized emulsion was sterilized at $121^{\circ} \mathrm{C}$ for $3 \mathrm{~s}$ and cooled to $10^{\circ} \mathrm{C}$. The prepared emulsion was then transferred to Samyang Packaging Co., Ltd. (Jincheon, Korea) for aseptic filling. Water-soluble vitamins and mineral salts were added to the emulsion, and the emulsion was diluted with water until it was reached the required concentration for LIF. The LIF was then homogenized at 240 bar and sterilized by an ultra-high temperature (UHT) process at $136^{\circ} \mathrm{C}$ for $35 \mathrm{~s}$. The sterilized LIF was cooled to $25^{\circ} \mathrm{C}$ and filled into $200 \mathrm{~mL}$ polyethylene terephthalate (PET) bottles under aseptic conditions.

The final composition of the LIF is shown in Table 1. In order to evaluate the influence of temperature on the physicochemical properties of the LIF during storage, it was stored in incubators at different temperatures (10, 20, 30, and $40^{\circ} \mathrm{C}$ ) for 6 mon. 
Table 1. Nutritional composition of LIF

\begin{tabular}{|c|c|c|}
\hline Nutritional composition & Unit & Content \\
\hline Carbohydrates & $\mathrm{g} / 100 \mathrm{~g}$ & 5.97 \\
\hline Sugars (lactose, fructose, glucose, sucrose, maltose) & $\mathrm{g} / 100 \mathrm{~g}$ & 4.91 \\
\hline Proteins & $\mathrm{g} / 100 \mathrm{~g}$ & 2.13 \\
\hline Lipids & $\mathrm{g} / 100 \mathrm{~g}$ & 3.71 \\
\hline Oleic acid & $\mathrm{g} / 100 \mathrm{~g}$ & 0.86 \\
\hline Linoleic acid & $\mathrm{g} / 100 \mathrm{~g}$ & 0.56 \\
\hline$\alpha$-Linolenic acid & $\mathrm{g} / 100 \mathrm{~g}$ & 0.05 \\
\hline Arachidonic acid & $\mathrm{g} / 100 \mathrm{~g}$ & 0.01 \\
\hline Docosahexaenoic acid (DHA) & $\mathrm{g} / 100 \mathrm{~g}$ & 0.01 \\
\hline \multicolumn{3}{|l|}{ Vitamins } \\
\hline Vitamin A & $\mathrm{mg} R E / 100 \mathrm{~g}^{1)}$ & 0.10 \\
\hline Vitamin $B_{1}$ & $\mathrm{mg} / 100 \mathrm{~g}$ & 0.09 \\
\hline Vitamin $\mathrm{B}_{2}$ & $\mathrm{mg} / 100 \mathrm{~g}$ & 0.23 \\
\hline Vitamin $\mathrm{B}_{6}$ & $\mathrm{mg} / 100 \mathrm{~g}$ & 0.06 \\
\hline Vitamin C & $\mathrm{mg} / 100 \mathrm{~g}$ & 13.5 \\
\hline Vitamin D & $\mu \mathrm{g} / 100 \mathrm{~g}$ & 1.65 \\
\hline Vitamin E & $\operatorname{mg} \alpha-\mathrm{TE} / 100 \mathrm{~g}^{2)}$ & 1.37 \\
\hline Vitamin K & $\mu \mathrm{g} / 100 \mathrm{~g}$ & 8.23 \\
\hline Folic acid & $\mu \mathrm{g} / 100 \mathrm{~g}$ & 7.67 \\
\hline Biotin & $\mu \mathrm{g} / 100 \mathrm{~g}$ & 3.97 \\
\hline Niacin & $\mathrm{mg} / 100 \mathrm{~g}$ & 0.69 \\
\hline Pantothenic acid & $\mathrm{mg} / 100 \mathrm{~g}$ & 0.85 \\
\hline \multicolumn{3}{|l|}{ Minerals } \\
\hline Calcium & $\mathrm{mg} / 100 \mathrm{~g}$ & 68.3 \\
\hline Potassium & $\mathrm{mg} / 100 \mathrm{~g}$ & 84.7 \\
\hline Iron & $\mathrm{mg} / 100 \mathrm{~g}$ & 1.25 \\
\hline Magnesium & $\mathrm{mg} / 100 \mathrm{~g}$ & 7.26 \\
\hline Zinc & $\mathrm{mg} / 100 \mathrm{~g}$ & 0.52 \\
\hline Copper & $\mu \mathrm{g} / 100 \mathrm{~g}$ & 39.5 \\
\hline Selenium & $\mu \mathrm{g} / 100 \mathrm{~g}$ & 2.43 \\
\hline
\end{tabular}

1) $1 \mathrm{mg}$ RE (retinol equivalent) $=1 \mathrm{mg}$ all-trans retinol.

2) $1 \mathrm{mg} \alpha$-TE ( $\alpha$-tocopherol equivalent $)=1 \mathrm{mg} \mathrm{d}$ - $\alpha$-tocopherol.

LIF, liquid infant formula.

\section{Analysis of 5-hydroxymethylfurfural (HMF) content}

The HMF content of the LIF was determined by a slightly modified Keeney and Bassette (1959) method. The LIF was diluted 20 times with distilled water and $10 \mathrm{~mL}$ aliquots of the diluted sample were pipetted into $50 \mathrm{~mL}$ test tubes, followed by the addition of $5 \mathrm{~mL} 0.3 \mathrm{~N}$ oxalic acid solution. After sealing with caps, the test tubes were heated in a water bath at $99^{\circ} \mathrm{C}$ 


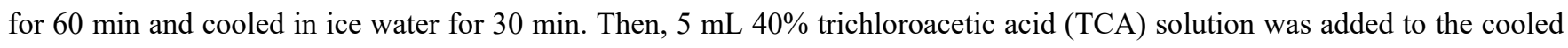
sample, which was subsequently filtered using a Whatman filter paper No.42. The filtrate $(4 \mathrm{~mL})$ was pipetted into $15 \mathrm{~mL}$ conical tubes, and $0.05 \mathrm{M}$ thiobarbituric acid (TBA) solution $(1 \mathrm{~mL})$ was added. After incubation at $40^{\circ} \mathrm{C}$ for 40 min, the conical tubes were cooled in ice water for $10 \mathrm{~min}$, and then the absorbance of the samples was measured using a UV spectrophotometer (UV-2600; Shimadzu Co., Kyoto, Japan) at $443 \mathrm{~nm}$. A standard curve was obtained by plotting absorbance at $443 \mathrm{~nm}$ of certain HMF concentrations, and a blank was prepared using distilled water instead of LIF.

\section{Color determination}

The color of the LIF during storage was measured using a colorimeter (Colorflex; Hunter Associates Laboratory Inc., Reston, VA, USA). All measurements were carried out in triplicate for each sample, and calibration was performed using a color standard white tile $(\mathrm{x}=80.32 ; \mathrm{y}=85.18 ; \mathrm{z}=89.28)$ prior to measurement. The results were expressed in terms of $\mathrm{L}^{*}$ value (lightness), $a^{*}$ value (redness), and $b^{*}$ value (yellowness). The range of $L^{*}$ values is from 0 (black) to 100 (white). The $a^{*}$ value ranges from +60 (red) to -60 (green), and the $b^{*}$ value ranges from +60 (yellow) to -60 (blue).

\section{$\mathrm{pH}$ measurement}

The $\mathrm{pH}$ level of the LIF samples was determined by a commercial $\mathrm{pH}$ meter (Orion Star ${ }^{\mathrm{TM}} \mathrm{A} 211$; Thermo Fisher Scientific Company, Waltham, MA, USA), and the $\mathrm{pH}$ measurements were performed after the temperature of the LIF had reached at $20^{\circ} \mathrm{C}$.

\section{Measurement of fat globule size and distribution}

Determination of fat globule size and distribution was carried out using a laser light scattering droplet size analyzer (Mastersizer 3000; Malvern Instruments Ltd., Worcestershire, UK). The refractive index and adsorption of the LIF were set at 1.462 and 0.01 , respectively. Water was used as continuous phase, and the refractive index of the water was 1.330 . In order to investigate the fat globule size distribution of LIF stored at different temperatures for 6 mon, the $\mathrm{D}[3,2], \mathrm{D}[4,3]$ and span values were used to interpret the fat globule size distribution. The span value is the dispersion index, and the D[3,2] and $\mathrm{D}[4,3]$ values are the surface-weighted mean and the volume-weighted mean, respectively. These values were calculated by Eqs. 1-3, respectively:

$$
\begin{aligned}
& \mathrm{D}[3,2]=\frac{\sum n_{i} d_{i}{ }^{3}}{\sum n_{i} d_{i}{ }^{2}} \\
& \mathrm{D}[4,3]=\frac{\sum n_{i} d_{i}{ }^{4}}{\sum n_{i} d_{i}{ }^{3}} \\
& \text { Span }=\frac{D v 90-D v 10}{D v 50}
\end{aligned}
$$

where $d_{i}$ is the average diameter of the $i$ class interval and $n_{i}$ is the number of droplets with diameter $d_{i}$. The Dv10, Dv50 and Dv90 values are average fat globule sizes corresponding to the cumulative distribution at $10 \%, 50 \%$, and $90 \%$, respectively. 


\section{Rheological measurement}

The rheological properties of the LIF were determined using a rheometer (HAKKE Roto Visco-1; Thermo Fisher Scientific, Karlsruhe, Germany) with a plate-plate system (35 mm in diameter with a gap of $500 \mu \mathrm{m}$ ) after storage for 6 mon. Steady shear data were obtained over a shear rate range of $1-300 \mathrm{~s}^{-1}$ at $25^{\circ} \mathrm{C}$. In order to describe the steady shear rheological properties of the LIF, the data were fitted to the well-known power law model (Eq. 4).

$$
\sigma=K \dot{\gamma}^{n}
$$

where $\sigma$ is the shear stress $(\mathrm{Pa}), \dot{\gamma}$ is the shear rate $\left(\mathrm{s}^{-1}\right), \mathrm{K}$ is the consistency index $\left(\mathrm{Pa} \mathrm{s}^{\mathrm{n}}\right)$, and $\mathrm{n}$ is the flow behavior index (dimensionless). The apparent viscosity $\left(\eta_{\mathrm{a}, 10}\right)$ at $10 \mathrm{~s}^{-1}$ was calculated from magnitudes of $n$ and $\mathrm{K}$.

\section{Statistical analysis}

All results are presented in means \pm standard deviation. Statistical analysis was performed using one-way ANOVA followed by Duncan's test with IBM SPSS Statistics 24 (IBM Software, Somers, NY, USA), and the level of significance was determined at $\mathrm{p}<0.05$.

\section{Results and Discussion}

\section{HMF content}

The initial HMF content of fresh LIF was $69.2 \mu \mathrm{M} / \mathrm{L}$ (Table 2). All the LIF samples showed a progressive increase in HMF content upon storage at different temperatures, and this result is consistent with that of Chávez-Servín et al. (2015), who noted the formation of HMF as storage time increases. Chávez-Servínet al. (2005) also reported that HMF content increases with increased storage temperature, and this is also consistent with our results. In the current study, LIF stored at $40^{\circ} \mathrm{C}(314$ $\mu \mathrm{M} / \mathrm{L})$ has a higher $\mathrm{HMF}$ content than that stored at $10^{\circ} \mathrm{C}(255 \mu \mathrm{M} / \mathrm{L})$ for 6 mon. These results indicate that the MR proceeds more rapidly at higher storage temperatures. Infant formula is very sensitive to the MR because it has high contents of lactose and lysine-rich proteins. Vitamin A and iron in infant formulas can also have a strong influence on the MR. Consequently, infant formulas can be more susceptible to the MR than bovine milk (Albalá-Hurtado et al., 1999; Ferrer et al., 2000). Therefore, HMF can be used as a sensitive indicator to evaluate the MR in LIF during storage.

The range of HMF contents in milk-based baby food is typically $0.18-0.25 \mathrm{mg} / \mathrm{kg}$ (Capuano and Fogliano, 2011). Although it is not clear whether or not HMF has negative effects on human health, it causes colon and liver cancer in rats and mice and induces genotoxic and mutagenic activity in bacteria (Nguyen et al., 2016; Van Der Fels-Klerx et al., 2014). Kavousi et al. (2015) pointed out that 5-sulfoxymethylfurfural (SMF), which is produced by bioconversion of HMF, is a major concern regarding the toxicity of HMF. SMF can induce damage in liver and kidney tissue and react with DNA, resulting in it presenting more toxic and mutagenic effects than HMF (Capuano and Fogliano, 2011; Kavousi et al., 2015). According to Zhang et al. (2016), HMF is converted by sulfotransferases into SMF, and humans express sulfotransferases in many tissues. Because rodents only express sulfotransferases in the liver, it is possible that HMF would have more negative effects in humans than in mice. Therefore, we recommend that LIF should be stored at low temperatures to ensure low HMF levels.

\section{Color}

Table 2 shows the $\mathrm{L}^{*}$ (lightness), $\mathrm{a}^{*}$ (redness), and $\mathrm{b}^{*}$ (yellowness) values of LIF stored at different temperatures for 6 
Table 2. HMF contents and color changes of LIF stored at different temperatures for 6 mon

\begin{tabular}{|c|c|c|c|c|c|}
\hline \multirow{2}{*}{$\begin{array}{l}\text { Temperature } \\
\left({ }^{\circ} \mathrm{C}\right)\end{array}$} & \multirow{2}{*}{ Mon } & \multirow{2}{*}{$\operatorname{HMF}(\mu \mathrm{M} / \mathrm{L})$} & \multicolumn{3}{|c|}{ Color } \\
\hline & & & $\mathrm{L}^{*}$ & $a^{*}$ & $\mathrm{~b}^{*}$ \\
\hline- & 0 & $69.2 \pm 1.16^{\mathrm{a}}$ & $67.7 \pm 0.08^{\mathrm{a}}$ & $0.79 \pm 0.04^{\mathrm{a}}$ & $11.0 \pm 0.01^{\mathrm{a}}$ \\
\hline \multirow[t]{6}{*}{10} & 1 & $118 \pm 8.39^{b}$ & $66.2 \pm 0.01^{\mathrm{b}}$ & $1.38 \pm 0.00^{\mathrm{b}}$ & $11.1 \pm 0.03^{\mathrm{b}}$ \\
\hline & 2 & $156 \pm 6.94^{\mathrm{cd}}$ & $66.0 \pm 0.01^{\mathrm{c}}$ & $1.48 \pm 0.01^{\mathrm{c}}$ & $11.1 \pm 0.02^{\mathrm{ab}}$ \\
\hline & 3 & $189 \pm 7.12^{\mathrm{ef}}$ & $65.4 \pm 0.01^{\mathrm{d}}$ & $1.59 \pm 0.01^{\mathrm{d}}$ & $11.3 \pm 0.02^{\mathrm{c}}$ \\
\hline & 4 & $223 \pm 15.8^{\mathrm{g}}$ & $64.7 \pm 0.02^{\mathrm{e}}$ & $1.73 \pm 0.04^{\mathrm{e}}$ & $11.3 \pm 0.07^{\mathrm{d}}$ \\
\hline & 5 & $235 \pm 7.95^{\mathrm{gh}}$ & $64.7 \pm 0.02^{\text {ef }}$ & $1.85 \pm 0.02^{\mathrm{f}}$ & $11.4 \pm 0.03^{\mathrm{d}}$ \\
\hline & 6 & $255 \pm 9.70^{\mathrm{ij}}$ & $64.6 \pm 0.02^{\mathrm{fg}}$ & $1.96 \pm 0.02^{\mathrm{g}}$ & $11.4 \pm 0.04^{\mathrm{e}}$ \\
\hline \multirow[t]{6}{*}{20} & 1 & $133 \pm 6.67^{\mathrm{k}}$ & $64.9 \pm 0.01^{\mathrm{h}}$ & $1.61 \pm 0.02^{\mathrm{d}}$ & $11.4 \pm 0.04^{\mathrm{e}}$ \\
\hline & 2 & $170 \pm 6.67^{\mathrm{dl}}$ & $64.4 \pm 0.01^{\mathrm{g}}$ & $1.99 \pm 0.02^{\mathrm{g}}$ & $11.4 \pm 0.01^{\mathrm{e}}$ \\
\hline & 3 & $203 \pm 8.25^{\mathrm{f}}$ & $63.9 \pm 0.01^{\mathrm{i}}$ & $2.09 \pm 0.01^{\mathrm{h}}$ & $11.6 \pm 0.03^{\mathrm{f}}$ \\
\hline & 4 & $224 \pm 17.6^{\mathrm{g}}$ & $63.3 \pm 0.06^{j}$ & $2.33 \pm 0.01^{\mathrm{i}}$ & $11.8 \pm 0.07^{\mathrm{g}}$ \\
\hline & 5 & $247 \pm 6.91^{\mathrm{hi}}$ & $62.8 \pm 0.14^{\mathrm{k}}$ & $2.44 \pm 0.02^{j}$ & $11.9 \pm 0.04^{\mathrm{h}}$ \\
\hline & 6 & $272 \pm 13.4^{\mathrm{mn}}$ & $62.4 \pm 0.26^{1}$ & $2.47 \pm 0.03^{\mathrm{j}}$ & $11.8 \pm 0.05^{\mathrm{gi}}$ \\
\hline \multirow[t]{6}{*}{30} & 1 & $140 \pm 3.33^{\mathrm{k}}$ & $63.7 \pm 0.01^{\mathrm{m}}$ & $2.33 \pm 0.01^{\mathrm{i}}$ & $11.9 \pm 0.01^{\mathrm{hi}}$ \\
\hline & 2 & $182 \pm 5.09^{\mathrm{el}}$ & $62.5 \pm 0.00^{1}$ & $2.46 \pm 0.02^{\mathrm{j}}$ & $12.0 \pm 0.04^{\mathrm{j}}$ \\
\hline & 3 & $222 \pm 8.74^{\mathrm{g}}$ & $61.4 \pm 0.01^{\mathrm{n}}$ & $2.72 \pm 0.01^{\mathrm{j}}$ & $12.6 \pm 0.02^{\mathrm{k}}$ \\
\hline & 4 & $268 \pm 8.98^{\mathrm{jm}}$ & $60.6 \pm 0.08^{\circ}$ & $3.29 \pm 0.01^{1}$ & $13.1 \pm 0.01^{1}$ \\
\hline & 5 & $274 \pm 7.64^{\mathrm{mn}}$ & $60.0 \pm 0.02^{\mathrm{p}}$ & $3.39 \pm 0.03^{\mathrm{m}}$ & $13.3 \pm 0.05^{\mathrm{m}}$ \\
\hline & 6 & $287 \pm 14.1^{\text {no }}$ & $59.0 \pm 0.04^{\mathrm{q}}$ & $3.49 \pm 0.05^{\mathrm{n}}$ & $13.2 \pm 0.01^{\mathrm{n}}$ \\
\hline \multirow[t]{6}{*}{40} & 1 & $144 \pm 5.09^{\mathrm{ck}}$ & $62.1 \pm 0.00^{\mathrm{r}}$ & $2.99 \pm 0.05^{\circ}$ & $12.7 \pm 0.03^{\circ}$ \\
\hline & 2 & $190 \pm 3.33^{\text {ef }}$ & $59.9 \pm 0.02^{\mathrm{s}}$ & $3.70 \pm 0.02^{p}$ & $13.6 \pm 0.04^{p}$ \\
\hline & 3 & $228 \pm 8.07 \mathrm{~g}$ & $57.9 \pm 0.01^{\mathrm{t}}$ & $4.12 \pm 0.03^{q}$ & $14.6 \pm 0.01^{\mathrm{q}}$ \\
\hline & 4 & $281 \pm 5.76^{\mathrm{mn}}$ & $56.6 \pm 0.01^{\mathrm{u}}$ & $4.88 \pm 0.02^{\mathrm{r}}$ & $15.6 \pm 0.02^{\mathrm{r}}$ \\
\hline & 5 & $301 \pm 3.83^{\text {op }}$ & $55.2 \pm 0.11^{\mathrm{v}}$ & $5.22 \pm 0.02^{\mathrm{s}}$ & $16.2 \pm 0.04^{\mathrm{s}}$ \\
\hline & 6 & $314 \pm 7.83^{p}$ & $53.7 \pm 0.11^{\mathrm{w}}$ & $5.31 \pm 0.06^{\mathrm{t}}$ & $16.2 \pm 0.04^{\mathrm{s}}$ \\
\hline
\end{tabular}

\footnotetext{
1) Values are the mean $\pm \mathrm{SD}$ of triplicate measurements.

${ }^{2)}$ Mean values in the same column with different letters are significantly different $(\mathrm{p}<0.05)$.

HMF, hydroxymethylfurfural; LIF, liquid infant formula.
}

mon. The $\mathrm{L}^{*}$ value decreased with storage time. This result agrees with that reported by other authors for milk-based products (Ferrer et al., 2005; Pereda et al., 2007), and the decrease in L* value indicates that LIF becomes darker in color. The visual appearance of LIF stored at $40^{\circ} \mathrm{C}$ was darkest after storage for 6 mon (Fig. 1). In contrast to the $\mathrm{L}^{*}$ value, the $\mathrm{a}^{*}$ and $\mathrm{b}^{*}$ values increased with storage time. These results are similar to those reported by Gaucher et al. (2008) for semi-skimmed UHT milk and Sawale et al. (2015) for a herb milk model system. The color changes were greater for LIF stored at $40^{\circ} \mathrm{C}$ than LIF stored at $10^{\circ} \mathrm{C}$. This tendency can be attributed to an increase in brown pigments produced by the MR, which is accelerated at higher storage temperatures (Ferrer et al., 2005; Zulueta et al., 2013). The MR is affected by many factors such as reducing sugars, lysine-rich proteins, high temperature, humidity, and storage period (Chávez-Servín et al., 2005). Infant 


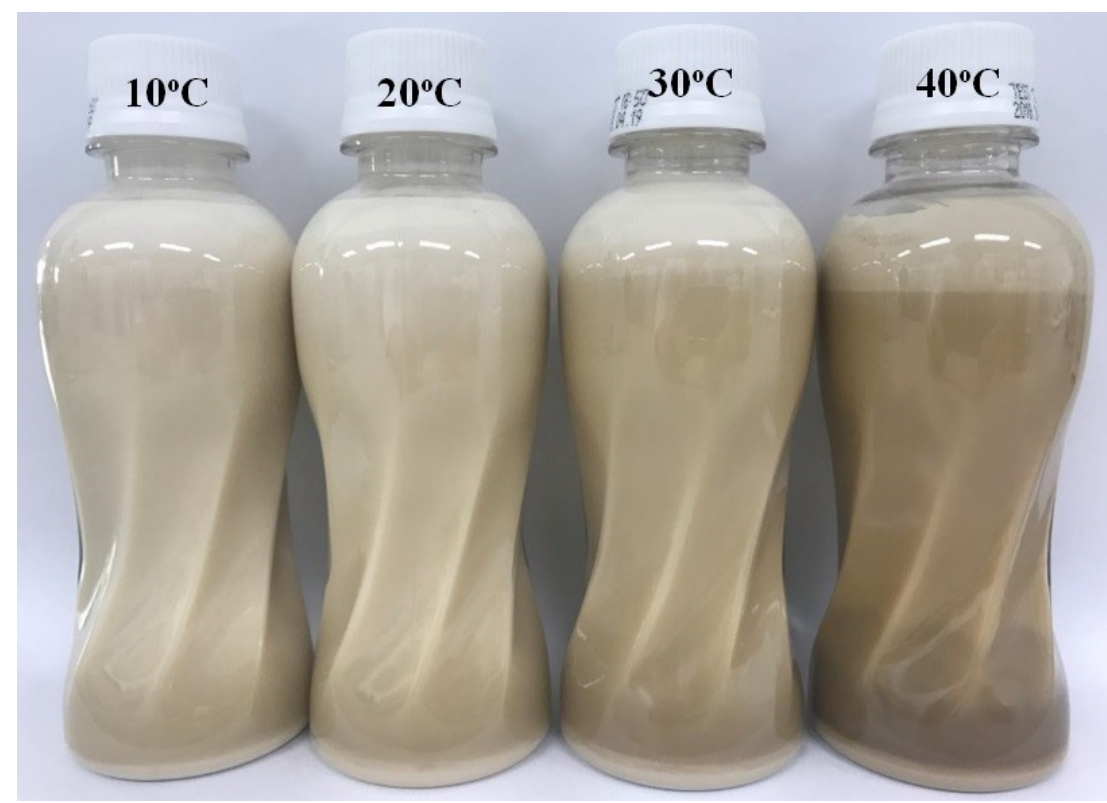

Fig. 1. Visual appearance of LIF after storage for 6 mon at different temperatures.

formula is more susceptible to the MR than bovine milk owing to the high content of lactose (Albalá-Hurtado et al., 1999; Ferrer et al., 2000). Thus, the MR can be accelerated by storage conditions and affects the color of LIF during storage.

\section{$\mathrm{pH}$}

The $\mathrm{pH}$ value of LIF stored at $10^{\circ} \mathrm{C}$ did not change during storage for 6 mon. However, a decrease in $\mathrm{pH}$ was observed in LIF stored at $30^{\circ} \mathrm{C}$ and $40^{\circ} \mathrm{C}$ (Table 3), and the rate of decrease in $\mathrm{pH}$ was greater for storage at $40^{\circ} \mathrm{C}$ than at $20^{\circ} \mathrm{C}$ and $30^{\circ} \mathrm{C}$. The decrease in $\mathrm{pH}$ of milk-based products during storage can be explained by proteolytic enzyme activity and the MR. Proteolysis in milk can be attributed to natural milk proteases and proteases produced by psychotropic bacteria (Malmgren et al., 2017). Because the LIF used in this study was manufactured under aseptic conditions, the reduction in $\mathrm{pH}$ can be attributed to proteolysis by a natural protease such as plasmin rather than that by bacteria. Plasmin is an alkaline protease in milk, and raw milk contains about $0.3 \mathrm{mg} / \mathrm{L}$ (Datta and Deeth, 2001). Because plasmin has strong heat resistance, it has activity even after UHT sterilization (Gaucher et al., 2008). According to Kelly and Foley (1997), the presence of plasmin in milk causes a significant decrease in $\mathrm{pH}$, and more protein degradation occurs at higher storage temperatures. The MR can also cause a decrease in $\mathrm{pH}$ by formation of various organic acids, and this reaction is enhanced at higher storage temperatures (Celestino et al., 1997). Therefore, protein degradation and the MR are accelerated at higher storage temperatures, resulting in a decrease in $\mathrm{pH}$.

\section{Fat globule size and distribution}

The fat globule sizes and distributions in LIF samples during storage for 6 mon are shown in Fig. 2 and Table 3. The fat globules in fresh LIF ( 0 mon) were smaller than those in human milk, ranging from 0.1 to $10 \mu \mathrm{m}$ (Michalski et al., 2005). This result is attributed to disruption during the homogenization process in the manufacture of LIF. The high pressure applied during homogenization breaks down the large fat globules into smaller fat globules (Floury et al., 2000; Seo et al., 2018). The span, $\mathrm{D}[3,2]$, and $\mathrm{D}[4,3]$ values of LIF stored at $10^{\circ} \mathrm{C}$ and $20^{\circ} \mathrm{C}$ did not change. However, all these values changed upon storage for 6 mon at $30^{\circ} \mathrm{C}$ and $40^{\circ} \mathrm{C}$. The span value of LIF stored at $30^{\circ} \mathrm{C}$ gradually increased during storage, indicating that 
Table 3. $\mathrm{pH}$ and fat globule size changes of LIF during storage for $\mathbf{6}$ mon at different temperatures

\begin{tabular}{|c|c|c|c|c|c|}
\hline \multirow{2}{*}{$\begin{array}{l}\text { Temperature } \\
\left({ }^{\circ} \mathrm{C}\right)\end{array}$} & \multirow{2}{*}{ Mon } & \multirow{2}{*}{$\mathrm{pH}(-)$} & \multicolumn{2}{|c|}{ Fat globule size $(\mu \mathrm{m})$} & \multirow{2}{*}{ Span (-) } \\
\hline & & & $\mathrm{D}[3,2]$ & $\mathrm{D}[4,3]$ & \\
\hline- & 0 & $7.03 \pm 0.05^{\mathrm{a}}$ & $0.41 \pm 0.01^{\mathrm{a}}$ & $0.57 \pm 0.01^{\mathrm{a}}$ & $1.66 \pm 0.05^{\mathrm{a}}$ \\
\hline \multirow[t]{6}{*}{10} & 1 & $7.02 \pm 0.02^{\mathrm{ab}}$ & $0.41 \pm 0.00^{\mathrm{a}}$ & $0.57 \pm 0.00^{\mathrm{a}}$ & $1.70 \pm 0.01^{\mathrm{a}}$ \\
\hline & 2 & $7.00 \pm 0.02^{\mathrm{abc}}$ & $0.41 \pm 0.00^{\mathrm{a}}$ & $0.57 \pm 0.00^{\mathrm{a}}$ & $1.71 \pm 0.01^{\mathrm{a}}$ \\
\hline & 3 & $6.99 \pm 0.02^{\mathrm{abcd}}$ & $0.40 \pm 0.01^{\mathrm{a}}$ & $0.57 \pm 0.00^{\mathrm{a}}$ & $1.72 \pm 0.02^{\mathrm{a}}$ \\
\hline & 4 & $7.00 \pm 0.02^{\mathrm{abc}}$ & $0.41 \pm 0.01^{\mathrm{a}}$ & $0.58 \pm 0.02^{\mathrm{a}}$ & $1.68 \pm 0.04^{\mathrm{a}}$ \\
\hline & 5 & $6.99 \pm 0.02^{\mathrm{abcd}}$ & $0.42 \pm 0.01^{\mathrm{a}}$ & $0.57 \pm 0.00^{\mathrm{a}}$ & $1.61 \pm 0.02^{\mathrm{a}}$ \\
\hline & 6 & $6.99 \pm 0.03^{\mathrm{abcd}}$ & $0.40 \pm 0.00^{\mathrm{a}}$ & $0.57 \pm 0.00^{\mathrm{a}}$ & $1.81 \pm 0.06^{\mathrm{ab}}$ \\
\hline \multirow[t]{6}{*}{20} & 1 & $6.98 \pm 0.02^{\mathrm{abcd}}$ & $0.41 \pm 0.00^{\mathrm{a}}$ & $0.57 \pm 0.00^{\mathrm{a}}$ & $1.70 \pm 0.01^{\mathrm{a}}$ \\
\hline & 2 & $6.96 \pm 0.02^{\mathrm{bcd}}$ & $0.41 \pm 0.00^{\mathrm{a}}$ & $0.57 \pm 0.01^{\mathrm{a}}$ & $1.71 \pm 0.01^{\mathrm{a}}$ \\
\hline & 3 & $6.94 \pm 0.04^{\mathrm{de}}$ & $0.40 \pm 0.01^{\mathrm{a}}$ & $0.59 \pm 0.01^{\mathrm{a}}$ & $1.80 \pm 0.05^{\mathrm{ab}}$ \\
\hline & 4 & $6.90 \pm 0.05^{\mathrm{ef}}$ & $0.41 \pm 0.00^{\mathrm{a}}$ & $0.58 \pm 0.01^{\mathrm{a}}$ & $1.74 \pm 0.03^{\mathrm{a}}$ \\
\hline & 5 & $6.87 \pm 0.02^{\mathrm{f}}$ & $0.43 \pm 0.02^{\mathrm{a}}$ & $0.63 \pm 0.02^{\mathrm{a}}$ & $1.87 \pm 0.10^{\mathrm{ab}}$ \\
\hline & 6 & $6.86 \pm 0.02^{f}$ & $0.41 \pm 0.01^{\mathrm{a}}$ & $0.67 \pm 0.03^{\mathrm{a}}$ & $1.99 \pm 0.06^{\mathrm{ab}}$ \\
\hline \multirow[t]{6}{*}{30} & 1 & $6.95 \pm 0.02^{\mathrm{cd}}$ & $0.43 \pm 0.01^{\mathrm{a}}$ & $0.66 \pm 0.01^{\mathrm{a}}$ & $2.10 \pm 0.05^{\mathrm{ab}}$ \\
\hline & 2 & $6.87 \pm 0.02^{\mathrm{f}}$ & $0.42 \pm 0.00^{\mathrm{a}}$ & $0.76 \pm 0.04^{\mathrm{a}}$ & $2.55 \pm 0.09^{\mathrm{bc}}$ \\
\hline & 3 & $6.81 \pm 0.03^{\mathrm{g}}$ & $0.47 \pm 0.00^{\mathrm{b}}$ & $1.17 \pm 0.05^{\mathrm{a}}$ & $5.40 \pm 0.15^{\mathrm{e}}$ \\
\hline & 4 & $6.75 \pm 0.03^{\mathrm{h}}$ & $0.60 \pm 0.01^{\mathrm{c}}$ & $2.47 \pm 0.25^{\mathrm{b}}$ & $10.4 \pm 1.04^{\mathrm{f}}$ \\
\hline & 5 & $6.68 \pm 0.02^{\mathrm{i}}$ & $0.66 \pm 0.03^{\mathrm{d}}$ & $2.93 \pm 0.43^{b}$ & $12.6 \pm 0.43^{\mathrm{g}}$ \\
\hline & 6 & $6.69 \pm 0.03^{\mathrm{i}}$ & $0.72 \pm 0.01^{\mathrm{e}}$ & $4.89 \pm 0.20^{\mathrm{c}}$ & $15.3 \pm 0.41^{\mathrm{h}}$ \\
\hline \multirow[t]{6}{*}{40} & 1 & $6.86 \pm 0.05^{\mathrm{f}}$ & $0.47 \pm 0.00^{\mathrm{b}}$ & $1.18 \pm 0.04^{\mathrm{a}}$ & $5.44 \pm 0.06^{\mathrm{e}}$ \\
\hline & 2 & $6.71 \pm 0.03^{\mathrm{hi}}$ & $0.74 \pm 0.05^{\mathrm{e}}$ & $4.42 \pm 0.14^{\mathrm{c}}$ & $15.3 \pm 1.77^{\mathrm{h}}$ \\
\hline & 3 & $6.62 \pm 0.05^{\mathrm{j}}$ & $1.08 \pm 0.00^{\mathrm{f}}$ & $6.91 \pm 0.19^{\mathrm{d}}$ & $5.16 \pm 0.16^{\mathrm{e}}$ \\
\hline & 4 & $6.55 \pm 0.03^{\mathrm{k}}$ & $1.61 \pm 0.05^{\mathrm{g}}$ & $12.6 \pm 1.25^{\mathrm{e}}$ & $3.61 \pm 0.03^{\mathrm{d}}$ \\
\hline & 5 & $6.48 \pm 0.02^{1}$ & $2.15 \pm 0.02^{\mathrm{h}}$ & $15.2 \pm 0.62^{\mathrm{f}}$ & $3.31 \pm 0.01^{\mathrm{d}}$ \\
\hline & 6 & $6.46 \pm 0.01^{1}$ & $2.54 \pm 0.04^{\mathrm{i}}$ & $17.7 \pm 0.97^{\mathrm{g}}$ & $2.29 \pm 0.09^{\mathrm{cd}}$ \\
\hline
\end{tabular}

\footnotetext{
1) Values are the mean $\pm \mathrm{SD}$ of triplicate measurements.

${ }^{2)}$ Mean values in the same column with different letters are significantly different $(p<0.05)$.

LIF, liquid infant formula.
}

the fat globule size distribution increases. In the case of LIF stored at $40^{\circ} \mathrm{C}$, the span value increased significantly up to 2 mon, and then gradually decreased from 2 to 6 mon. This is explained by the increased Dv90 and Dv50 values. LIF stored at $40^{\circ} \mathrm{C}$ had a high Dv90 value due to the tail in the large size region at 2 mon (Fig. 2), resulting in a large increase of span value. As the tail became a secondary peak in the large size region at 4 mon, the Dv50 value significantly increased, resulting in a decrease in span value.

The $\mathrm{D}[3,2]$ and $\mathrm{D}[4,3]$ values of LIF stored at $30^{\circ} \mathrm{C}$ and $40^{\circ} \mathrm{C}$ increased with storage time. These results indicate that the oil-in-water emulsion of the LIF is unstable at high storage temperatures. The structure of fat globules in infant formula is different compared to that of human milk. The surface of the fat globules in human milk comprises a tri-layered membrane 

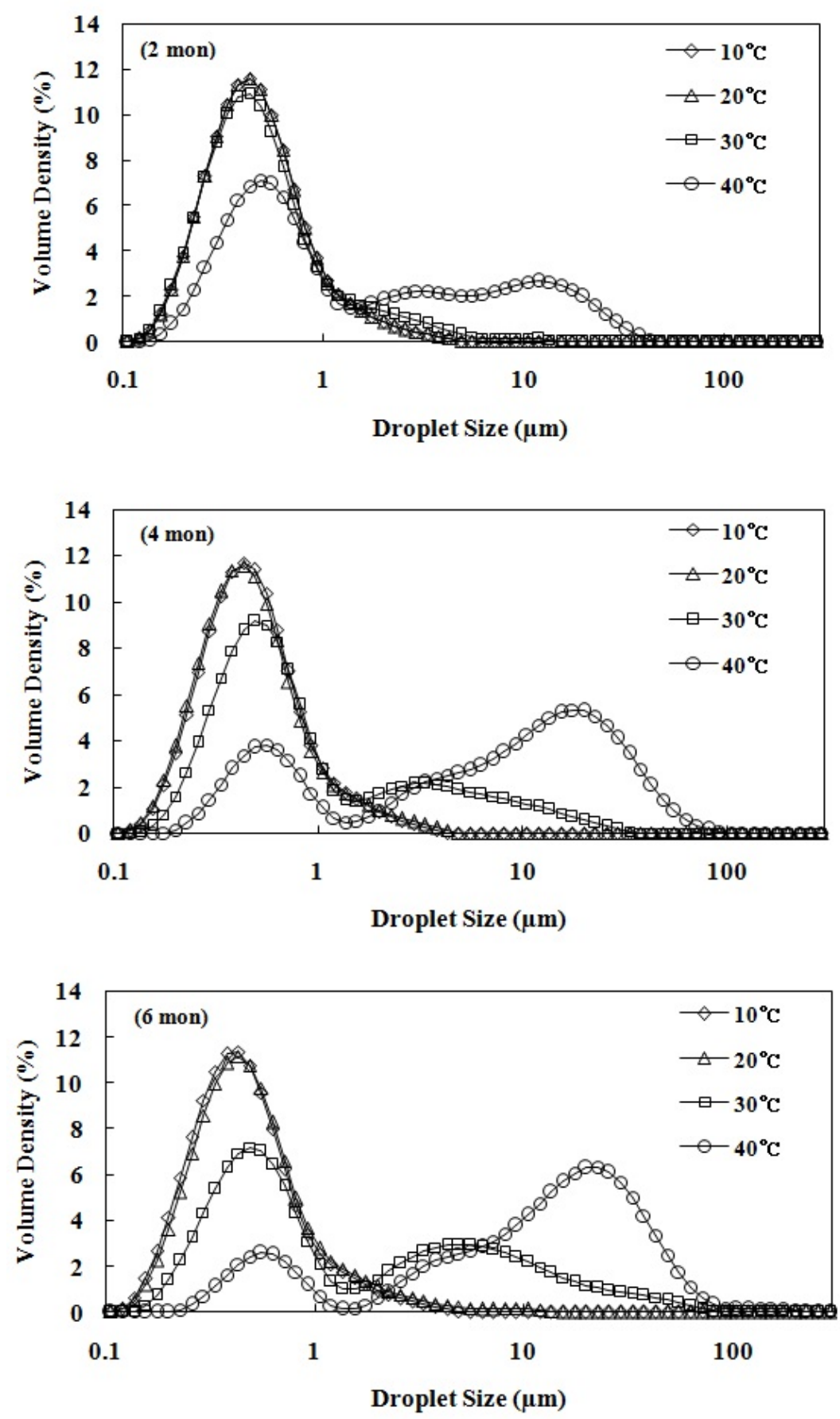

Fig. 2. Changes in fat globule size distribution for LIF during storage for 6 mon at different temperatures.

composed of phospholipids, proteins, and cholesterol, while the fat globules of infant formulas are stabilized by a protein layer composed of caseins and whey proteins (Gallier et al., 2015; Nguyen et al., 2018). Thus, LIF emulsions can be unstable at higher storage temperatures because fat globules covered by proteins are very sensitive to plasmin, which exhibits a higher level of proteolysis at higher storage temperatures (Kelly and Foley, 1997). According to Gaucher et al. (2008), a decrease in $\mathrm{pH}$ can also result in an unstable emulsion by changing the zeta-potential of fat globules stabilized by proteins. Fat globules covered with casein proteins have a net negative charge, and thus the stability of emulsions stabilized by casein proteins is ensured by electrostatic repulsions (Holt and Horne, 1996). However, if the $\mathrm{pH}$ of an emulsion decreases, its stability can be 
reduced due to neutralization of the negative charges on the fat globules (Gaucher et al., 2008). In this study, the D[4,3] and $\mathrm{D}[3,2]$ values of LIF stored at $30^{\circ} \mathrm{C}$ and $40^{\circ} \mathrm{C}$ increased with a decrease in $\mathrm{pH}$ (Table 3). Therefore, a decrease of $\mathrm{pH}$ can affect the stability of oil-in-water emulsions such as LIFs, resulting in an increase in fat globule size.

\section{Rheological properties}

The shear stress $(\sigma)$ versus shear rate $(\dot{\gamma})$ data for LIF samples stored at different temperatures were fitted to a power law model (Eq. 4) with high determination coefficients $(\mathrm{r}=0.91-0.96)$, as shown in Table 4. The flow behavior index (n) of LIF decreased with increasing storage temperature. LIF stored at $10^{\circ} \mathrm{C}$ exhibited a flow behavior index close to $1(\mathrm{n}=0.96)$, showing nearly Newtonian fluid properties. As storage temperature increased, the $\mathrm{n}$ value decreased upon storage for 6 mon, as evinced by LIF stored at $30^{\circ} \mathrm{C}(\mathrm{n}=0.88)$ and $40^{\circ} \mathrm{C}(\mathrm{n}=0.81)$. This result indicates that LIF stored at higher temperatures exhibits shear-thinning behavior. The shear-thinning behavior of oil-in-water emulsions such as LIF with milk fat is attributed to the deformation and breaking up of flocculated fat globules at high shear rates (Derkach, 2009; Seo et al., 2018). In this study, we found that flocculated fat globules were observed in LIF stored at $30^{\circ} \mathrm{C}$ and $40^{\circ} \mathrm{C}$ after 6 mon (Fig. 2). Thus, the flocculation of fat globules at high storage temperatures can lead to a lower $\mathrm{n}$ value, indicating shear-thinning behavior.

The apparent viscosity $\left(\eta_{\mathrm{a}, 10}\right)$ and consistency index $(\mathrm{K})$ of LIF after 6 mon increased as storage temperature increases. These results are attributed to gelation by proteolysis and polymerization of casein and whey proteins at high storage temperatures (Malmgren et al., 2017). Gelation by proteolysis can be caused by either milk proteinases such as plasmin or microbial proteinases. Plasmin can accelerate the release of $\beta$-lactoglobulin- $\kappa$-casein complexes by hydrolysis of casein proteins, and the released protein complex can aggregate, leading to soft gel formation (Datta and Deeth, 2001; Rauh et al., 2014). The MR can also lead to gel formation by polymerization of casein and whey proteins. In the MR process, Amadori products can combine with adjacent amino groups of proteins, resulting in the formation of advanced glycation end products (AGEs), which have a very complex combination structure (Ferrer et al., 2005; Malmgren et al., 2017). In this study, the apparent viscosity $\left(\eta_{\mathrm{a}, 10}\right)$ and consistency index $(\mathrm{K})$ after 6 mon increased concurrently with color change and HMF content, as shown Table 2 and Table 4. Guar et al. (2018) also reported that the sedimentation level of milk proteins increases as $\mathrm{pH}$ decreases below 6.7. Therefore, the gelation of milk proteins can be caused by a decrease in $\mathrm{pH}$ and, in this study, the $\eta_{\mathrm{a}, 10}$ and $\mathrm{K}$ values of LIF stored at $30^{\circ} \mathrm{C}$ and $40^{\circ} \mathrm{C}$ increased with decreasing $\mathrm{pH}$. This result was in good agreement with that of Rauh et al. (2014), who found that the viscosity of UHT milk increases with decreasing pH during storage for 16 wk. Thus, a high storage temperature can induce proteolysis, the MR, and $\mathrm{pH}$ decrease, and the rheological properties of LIF during storage are affected by these changes.

Table 4. Steady shear rheological properties of LIF after storage for 6 mon at different temperatures

\begin{tabular}{|c|c|c|c|c|}
\hline \multirow{2}{*}{ Temp $\left({ }^{\circ} \mathrm{C}\right)$} & \multirow{2}{*}{$\begin{array}{c}\text { Apparent viscosity } \\
\prod_{\mathrm{a}, 10}(\mathrm{mPa} \mathrm{s})\end{array}$} & \multicolumn{3}{|c|}{ Power law } \\
\hline & & $\mathrm{n}(-)$ & $\left.\mathrm{K}(\mathrm{mPa} \mathrm{s})^{\mathrm{n}}\right)$ & $r^{2}$ \\
\hline 10 & $2.61 \pm 0.26^{\mathrm{a}}$ & $0.96 \pm 0.05^{\mathrm{a}}$ & $2.92 \pm 0.63^{\mathrm{a}}$ & 0.91 \\
\hline 20 & $3.22 \pm 0.35^{\mathrm{a}}$ & $0.91 \pm 0.01^{\mathrm{ab}}$ & $3.92 \pm 0.47^{\mathrm{b}}$ & 0.95 \\
\hline 30 & $4.22 \pm 0.28^{b}$ & $0.88 \pm 0.01^{b c}$ & $5.58 \pm 0.25^{\mathrm{c}}$ & 0.96 \\
\hline 40 & $5.53 \pm 0.55^{\mathrm{c}}$ & $0.81 \pm 0.01^{\mathrm{c}}$ & $8.61 \pm 0.61^{\mathrm{d}}$ & 0.96 \\
\hline
\end{tabular}

1) Values are the mean $\pm \mathrm{SD}$ of triplicate measurements.

${ }^{2)}$ Mean values in the same column with different letters are significantly different $(p<0.05)$.

LIF, liquid infant formula. 


\section{Conclusions}

The physicochemical properties of LIF during storage for 6 mon were influenced by storage temperature. The fat globule size and $\mathrm{pH}$ of LIF stored at $10^{\circ} \mathrm{C}$ did not change during storage, but those of LIF stored at $30^{\circ} \mathrm{C}$ and $40^{\circ} \mathrm{C}$ change over 6 mon. The apparent viscosity $\left(\eta_{\mathrm{a}, 10}\right)$ and consistency index $(\mathrm{K})$ of LIF stored at higher temperatures $\left(30^{\circ} \mathrm{C}\right.$ and $\left.40^{\circ} \mathrm{C}\right)$ were higher than those of LIF stored at low temperatures $\left(10^{\circ} \mathrm{C}\right.$ and $\left.20^{\circ} \mathrm{C}\right)$. The color and HMF content of LIF gradually changed, even during storage at $10^{\circ} \mathrm{C}$ and $20^{\circ} \mathrm{C}$. In conclusion, the physicochemical changes of LIF during its shelf-life are significantly affected by storage temperature and are accelerated at high storage temperature. Most of ready-to-feed LIF products in global market have a shelf-life period of approximately 12 mon at room temperature from the date of production, and manufactures instruct to avoid the storage at extreme temperatures. Therefore, even if the LIF products in Korea are sterilized and have shelf-life of 6 mon, we recommend that they should be stored at low temperature to minimize their quality changes as much as possible in case of long-term storage.

\section{References}

Albalá-Hurtado S, Veciana-Nogués MT, Mariné-Font A, Vidal-Carou MC. 1999. Progress of browning reactions during storage of liquid infant milks. J Agric Food Chem 47:4033-4037.

Capuano E, Fogliano V. 2011. Acrylamide and 5-hydroxymethylfurfural (HMF): A review on metabolism, toxicity, occurrence in food and mitigation strategies. LWT-Food Sci Technol 44:793-810.

Celestino EL, Iyer M, Roginski H. 1997. Reconstituted UHT-treated milk: Effects of raw milk, powder quality and storage conditions of UHT milk on its physico-chemical attributes and flavour. Int Dairy J 7:129-140.

Chávez-Servín JL, Castellote AI, López-Sabater MC. 2005. Analysis of potential and free furfural compounds in milk-based formulae by high-performance liquid chromatography: Evolution during storage. J Chromatogr A 1076:133-140.

Chávez-Servín JL, Carbot KT, García-Gasca T, Castellote AI, López-Sabater MC. 2015. Content and evolution of potential furfural compounds in commercial milk-based infant formula powder after opening the packet. Food Chem 166:486-491.

Cheng H, Zhu RG, Erichsen H, Soerensen J, Petersen MA, Skibsted LH. 2017. High temperature storage of infant formula milk powder for prediction of storage stability at ambient conditions. Int Dairy J 73:166-174.

Datta N, Deeth HC. 2001. Age gelation of UHT milk - A review. Trans I ChemE 79:197-210.

Derkach SR. 2009. Rheology of emulsions. Adv Colloid Interface Sci 151:1-23.

Drapala KP, Auty MAE, Mulvihill DM, O'Mahony JA. 2016. Improving thermal stability of hydrolysed whey protein-based infant formula emulsions by protein-carbohydrate conjugation. Food Res Int 88:42-51.

Drapala KP, Auty MAE, Mulvihill DM, O’Mahony JA. 2017. Influence of emulsifier type on the spray-drying properties of model infant formula emulsions. Food Hydrocoll 69:56-66.

Ferrer E, Alegría A, Farré R, Abellán P, Romero F. 2000. Effects of thermal processing and storage on available lysine and furfural compounds contents of infant formulas. J Agric Food Chem 48:1817-1822.

Ferrer E, Alegría A, Farré R, Clemente G, Calvo C. 2005. Fluorescence, browning index, and color in infant formulas during storage. J Agric Food Chem 53:4911-4917.

Floury J, Desrumaux A, Lardières J. 2000. Effect of high-pressure homogenization on droplet size distributions and rheological properties of model oil-in-water emulsions. Innov Food Sci Emerg Technol 1:127-134.

Gallier S, Vocking K, Post JA, Van De Heijning B, Acton D, Van Der Beek EM, Van Baalen T. 2015. A novel infant milk 
formula concept: Mimicking the human milk fat globule structure. Colloids Surf B Biointerfaces 136:329-339.

Gaucher I, Mollé D, Gagnaire V, Gaucheron F. 2008. Effects of storage temperature on physico-chemical characteristics of semi-skimmed UHT milk. Food Hydrocoll 22:130-143.

Guar V, Schalk J, Anema SG. 2018. Sedimentation in UHT milk. Int Dairy J 78:92-102.

Guerra-Hernandez E, Gomez CL, Garcia-Villanova B, Sanchez NC, Gomez JMR. 2002. Effect of storage on non-enzymatic browning of liquid infant milk formulae. J Sci Food Agric 82:587-592.

Holt C, Horne DS. 1996. The hairy casein micelle: Evolution of the concept and its implications for dairy technology. Neth Milk Dairy J 50: 85-111.

Kavousi P, Mirhosseini H, Ghazali H, Ariffin AA. 2015. Formation and reduction of 5-hydroxymethylfurfural at frying temperature in model system as a function of amino acid and sugar composition. Food Chem 182:164-170.

Keeney M, Bassette R. 1959. Determination of intermediate compounds in dairy stages of browning reaction in milk products. J Dairy Sci 42:945-960.

Kelly AL, Foley J. 1997. Proteolysis and storage stability of UHT milk as influenced by milk plasmin activity, plasmin/ $\beta$ lactoglobulin complexation, plasminogen activation and somatic cell count. Int Dairy J 7:411-420.

Malmgren B, ARdö Y, Langton M, Altskär A, Bremer MGEG, Dejmek P, Paulsson M. 2017. Changes in proteins, physical stability and structure in directly heated UHT milk during storage at different temperatures. Int Dairy J 71:60-75.

McCarthy NA, Kelly AL, O'Mahony JA, Hickey DK, Chaurin V. 2012. Effect of protein content on emulsion stability of model infant formula. Int Dairy J 25:80-86.

Michalski M, Briard V, Michel F, Tasson F, Poulain P. 2005. Size distribution of fat globules in human colostrum, breast milk, and infant formula. J Dairy Sci 88:1927-1940.

Murphy EG, Roos YH, Hogan SA, Maher PG, Flynn CG, Fenelon MA. 2015. Physical stability of infant milk formula made with selectively hydrolysed whey proteins. Int Dairy J 40:39-46.

Nguyen HT, Van der Fels-Klerx HJ, Peters RJB, Van Boekel MAJS. 2016. Acrylamide and 5-hydroxymethylfurfural formation during baking of biscuits: Part I: Effects of sugar type. Food Chem 192:575-585.

Nguyen TTP, Bhandari B, Cichero J, Prakash S. 2018. In vitro lipolysis of dairy and soy based infant formula. Food Res Int 106:696-705.

Pereda J, Ferragut V, Quevedo JM, Guamis B, Trujillo AJ. 2007. Effects of ultra-high pressure homogenization on microbial and physicochemical shelf life of milk. J Dairy Sci 90:1081-1093.

Rauh VM, Sundgren A, Bakman M, Ipsen R, Paulsson M, Larsen LB, Hammershøj M. 2014. Plasmin activity as a possible cause for age gelation in UHT milk produced by direct steam infusion. Int Dairy J 38:199-207.

Sabater C, Montilla A, Ovejero A, Prodanov M, Olano A, Corzo N. 2018. Furosine and HMF determination in prebioticsupplemented infant formula from Spanish market. J Food Compos Anal 66:65-73.

Sawale PD, Singh RRB, Arora S. 2015. Stability and quality of herb (Pueraria tuberosa)-milk model system. J Food Sci Technol 52:1089-1095.

Seo CW, Kang SH, Shin YK, Yoo B. 2018. Effect of homogenization pressure and supplementation with sucrose fatty acid ester on the physical properties of dairy cream-based emulsions. Korean J Food Sci An 38:476-486.

Tham TWY, Yeoh ATH, Zhou W. 2017. Characterisation of aged infant formulas and physicochemical changes. Food Chem 219:117-125.

Van Der Fels-Klerx HJ, Capuano E, Nguyen HT, Ataç Mogol B, Kocadağlı T, Göncüoğlu Taş N, Hamzalığlu A, Van 
Boekel MAJS, Gökmen V. 2014. Acrylamide and 5-hydroxymethylfurfural formation during baking of biscuits: $\mathrm{NaCl}$ and temperature-time profile effects and kinetics. Food Res Int 57:210-217.

Zhang Z, Zou Y, Wu T, Huang C, Pei K, Zhan G, Lin X, Bai W, Ou S. 2016. Chlorogenic acid increased 5hydroxymethylfurfural formation when heating fructose alone or with aspartic acid at two $\mathrm{pH}$ levels. Food Chem 190:832-835.

Zulueta A, Barba FJ, Esteve MJ, Frígola A. 2013. Changes in quality and nutritional parameters during refrigerated storage of an orange juice-milk beverage treated by equivalent thermal and non-thermal processes for mild pasteurization. Food Bioprocess Technol 6:2018-2030. 